\title{
The Disputes between Appion and Clement in the Pseudo-Clementine Homilies: A Narrative and Rhetorical Approach to the Structure of Hom. 6
}

\author{
BENJAMIN DE VOS \\ Ghent University
}

\section{Introduction}

This contribution offers, in the first place (1), a structural and rhetorical reading of the debates on the third day between Clement and Appion in the Pseudo-Clementine Homilies (Hom. 6) and shows that there is a well-considered rhetorical ring structure in their disputes. Connected with this first point (2), the suggested reading will unravel how Clement and Appion use and manipulate their sophisticated rhetoric, linked to this particular structure. This is well worth considering since these debates deal with Greek paideia, which means culture and above all education, of which rhetorical education forms part. The rhetorical features will be displayed as a fine product of the rhetorical and even sophistic background in Late Antiquity. Clement, moreover, will present himself as a master in rhetoric against Appion, who is presented as a sophist and a grammarian in the Pseudo-Clementine Homilies. Until now, the Pseudo-Clementine research context concerning Hom. 6 has focused on two aspects. First, several researchers have examined to which tradition of Orphic Cosmogonies the Homilistic version, included in the speech of Appion, belongs. Secondly, according to some scholars, the disputes between Appion and Clement have an abrupt ending. However, they have not looked at the structure and function of the general debate between Clement and Appion and of the whole work. Finally (3), the reappraisal of the rhetorical dynamics in and the narrative structure of Hom. 6. will contribute to a better understanding of these disputes between Appion and Clement (Hom. 4-6) and their function in the Homilistic novel. 
The Pseudo-Clementine novel is considered by most scholars as the only (surviving) Christian (fringe) novel, related to the so-called 'Greek novels' such as Heliodorus' Aethiopica. ${ }^{1}$ There are two fourth-century text traditions of these Pseudo-Clementines: the Homilies (or Klementia) ${ }^{2}$ and the Recognitions, ${ }^{3}$ which would be two different and independent elaborations of a so-called Basic Writing. ${ }^{4}$ The Pseudo-Clementine novel presents itself as the autobiography of Clement of Rome ${ }^{5}$ during his time as Peter's follower. In both traditions, we read that Clement, as a young boy, was struggling with philosophical, existential questions, and, moreover, that he had lost his parents and brothers due to a family intrigue. He left pagan philosophical schools behind because they did not give any true answers - only varying hypotheses - to his questions such as 'Is there life after death?' or 'Is this world created, and was there anything before it was made?' (Hom. and Rec. 1.1). Later he meets Barnabas and Peter and converts to their religion which is clearly presented as the only answer to Clement's philosophical questions, marked by his baptism in Hom. 11.35 and Rec. 6.15. Peter subsequently helps him to recognise his lost family members in the second part of the story. In both traditions, we encounter a series of disputes between Peter and Simon Magus, Peter's main opponent, the symbol and 'father' of unorthodoxy in these Pseudo-Clementines (for example Hom. 16.21.3-4). ${ }^{6}$ A big difference, however, between the two traditions is that in the Homilistic version we encounter a series

${ }^{1}$ See e.g. Edwards 1992, 459-474.

${ }^{2}$ We have two extant manuscripts of these Homilies: Vaticanus Ottobonianus gr.443 $\left(14^{\text {th }}\right.$ or $16^{\text {th }} \mathrm{c}$.) and gr.930 in la Bibliotheque nationale de France in Paris $\left(11-12^{\text {th }} \mathrm{c}\right.$.). For other manuscripts which have small fragments of the Homilies, see Jones 2012, 10-11. The Homilies are divided into 20 books, also called Homilies. For the Greek version, see the edition of Rehm 1953.

${ }^{3}$ The Recognitions are divided into 10 books, and were originally written in Greek. This Greek version has been lost, except for a few extant excerpts (see Rehm 1956, Jones 2012, 11-13). At the beginning of the fifth century, Rufinus of Aquileia translated the Recognitions into Latin which had a big circulation in the Middle Ages. For the Latin edition of the Recognitions, see Rehm 1956. See for the most recent translated edition of both traditions: Geoltrain and Kaestli 2005. For a translated edition of the preserved Syriac version, which combines both traditions of the Homilies and the Recognitions: Jones 2014. For the important role of the Syriac version in the Quellenanalyse, see Richardson 1895 and Jones 2014.

${ }^{4}$ For (possible) witnesses of and quotes from this Basic Writing, see Jones 2012, 17-20.

${ }^{5}$ This character refers to the historical Clement of Rome (Irenaeus, Adversus Haereses, 3.3.3, and Eusebius, Historia Ecclesiastica, 3.4.9; 3.155) but we have to be aware that we are dealing with a composite literary character. See also Pouderon 2012, 2012a, and 2012b; Geoltrain and Kaestli 2005, 1175-1176; Jones 2012, 172-193.

${ }^{6}$ See for more information on the role of Simon Magus within Christian discourses: Haar 2003 and MacRae 2019. 
of disputes between Clement and the pagan Appion ${ }^{7}$ (Hom. 4-6), who is a follower of Simon. The latter disputes, held in Tyre (Lebanon), discuss Greek culture or paideia. They do not have a real structural counterpart in the Recognitions, except for several similar topics in chapter $10,17-51,{ }^{8}$ which (besides other arguments) ${ }^{9}$ has led to the conclusion that these Homilistic disputes between Clement and Appion have an intrusive character in the novel and come from another source. ${ }^{10} \mathrm{This}$ source-critical approach (in German: Quellenanalyse) had prevailed for the past centuries in the Pseudo-Clementine research context. Due to the narrative and generic complexity of this work and the similarities and differences of the PseudoClementine versions, researchers of the nineteenth and twentieth centuries, considered and approached the Pseudo-Clementines as a patchwork of different, and mostly hypothetical sources, of which the Jewish-Christian Grundschrift or Basic Writing (written in early third century) would be the main source, which has, however, not been preserved. ${ }^{11}$ In line with this approach, several researchers since Carl Schmidt have often supposed that Homilies 4 to 6 come from a so-called Alexandrian Hellenistic Disputationsbuch of the second century. ${ }^{12}$ Its inclusion in the later Pseudo-Clementine Homilies created some discrepancies with the rest of the Homilistic autobiographical story. André Siouville even stated that these disputes could be removed without any consequence for the rest of the story. ${ }^{13}$ In our view, tracing back these discussions to some sort of Disputationsbuch ${ }^{14}$ resulted in a certain loss of our understanding of the meaningful complexity of these

7 'Apion' refers to the historical character and 'Appion' to the narrative figure in the Homilies, see Bremmer 2010, 72-91, and his updated version in Bremmer 2017, 251-265.

${ }^{8}$ In this passage, Peter, Clement, and his brothers Nicetas and Aquila discuss astrology, mythology, Orphic cosmogony, allegory and the doctrine of the True Prophet. These topics are not developed in the same way as they are in the Homilistic disputes with Appion, see for a more detailed and schematic comparison: Strecker 1958, 80.

${ }^{9}$ See for a full discussion, De Vos 2019.

${ }^{10}$ See e.g. Waitz 1904, 251-256; Heintze 1914, 19; 22-23; 43-45; 50: E.g. 22-23: ,Man muß den Mut haben zu bekennen, daß die Apiondisputationen in der Grundschrift höchst unpassend gewesen sein würden. Die Annahme, daß sie wirklich dort gestanden haben, ist aus inneren und äußeren Gründen zu verwerfen [...].'

${ }^{11}$ For more information (and more possible sources): Jones 1982, 1-33, 63-96; especially 818.

12 Schmidt 1929, 298; see e.g. Edwards 1992, 461; 463; Adler 1993, 28-30.

${ }^{13}$ Siouville $(1991,21)$ wrote: 'Les Homélies $I V, V$, VI, qui nous les rapportent, pourraient être supprimées, sans interrompre la suite de l'ouvrage'.

${ }^{14}$ Bernard Pouderon reacts against this Disputations-hypothesis and states that Hom. 4-6, the disputes between Appion and Clement, were already part of the Jewish-Hellenistic Vorlage which would have been the basis of the Jewish-Christian Grundschrift. In this way, the Homilistic version has better preserved the original structure of this Jewish-Hellenistic 
Homilies. In the last decades, however, a shift occurred to a narrative-rhetorical and structural approach of the different Pseudo-Clementine traditions as we have them, ${ }^{15}$ including the Homilistic disputes between Appion and Clement. ${ }^{16}$ For example, A.Y. Reed wrote about the main theme of Judeo-Christianity in the whole work, connecting Hom. 4-6 (mainly Hom. 4 and 5) with the rest of the Homilies considering what the passage of Hom. 4-6 could tell us about its fourth-century authors/redactors. ${ }^{17}$ This approach is especially interesting since the Homilies and the Recognitions each have their own narrative logic. ${ }^{18}$ In line and in support of this approach, my contribution intends to provide a more extensive, rhetorical and structural analysis of the disputes on the third day (Hom. 6) which has been neglected in previous Pseudo-Clementine research, in order to better understand its function in the whole of the novel. We should, however, not neglect the Recognitions, which can be the danger of such an approach. Therefore, I will refer to and compare with the Recognitions where necessary for our interpretation of the Homilies.

\section{The general structure of Hom. 6 and the Homilistic Orphic Cosmogony (6.2-6.16)}

The disputes between Clement and Appion (Homilies 4-6) last for three days. On the first day (4.7-25), Clement rejects Greek paideia as a cultural and educational format and specifically the Greek myths about the gods. On the second day (5.130), Appion wants to defend the myths with an allegorical interpretation, but he is ill and, hence, absent. Clement uses this moment to tell an anecdote from his youth. Appion was a friend of his father's and saw, during a visit, that the young Clement was ill. He suspected that Clement was lovesick and tried to help him with an ode to adultery, which we can read in line with the tradition of encomia ${ }^{19}$

Vorlage than the version of the Recognitions has done. Pouderon dates this Jewish-Hellenistic Vorlage at the beginning of the second century. Pouderon 2012a, 21-46, in particular $38-41$, and 2012c, 83 .

${ }^{15}$ See Côté 2001, Kelley 2006 and Duncan 2017.

${ }^{16}$ See also De Vos 2017, 203-229 and 2019, 54-88 on the role of Hom. 4-6 in the whole Homilies.

${ }^{17}$ Reed 2008, 351-359.

18 As Amsler $(2014,178)$ writes: 'Although it is common to refer to the "Pseudo-Clementines" as a single composition, the Homilies and the Recognitions each follow their own narrative logic. Methodologically, it is important to examine each document for itself and resist the temptation to harmonize.'

${ }^{19}$ For more information on encomia as autonomous genre and as progymnastic exercise, see: Pernot 1993, passim; Whitmarsh 2005, 77-79. 
and letters on love stretching from Plato's Symposium and Gorgias' Encomium on Helen to the Second Sophistic, such as Pseudo-Lucian's Affairs of the Heart. Appion's encomium in epistolary form was meant to convince a matrona, a Roman, married woman, of all the benefits of adultery. However, this Roman matrona did not exist because Clement was lying about his lovesickness. The real reason of Clement's sickness was not his longing for a woman, but for true knowledge, which he was not able to find in the pagan world, in particular the philosophical schools, characterised as a world filled with constantly changing hypotheses. This fits in with the dispute on the first day when Greek paideia, including the educational component of which the encomium is a product, had been rejected. Appion's allegorical defence of the Greek myths eventually forms the subject of the third day (6.1-25). On this last day, Appion wants to explain, by using a unique version of an Orphic Cosmogony, ${ }^{20}$ how the universe is created by Phanes and how in fact the Greek gods should be allegorically seen as forces of nature.

One of the main points of focus concerning Hom. 6, in line with the Quellenanalyse, was this unique version of an Orphic Cosmogony. ${ }^{21}$ Researchers such as Luc Brisson, Otto Gruppe, Fabienne Jourdan, Otto Kern, Lautaro Roig Lanzillotta and several others have examined to which tradition of Orphic Cosmogonies this Homilistic version belongs. ${ }^{22}$ These researchers, however, do not provide any

${ }^{20}$ We do not have any information, however, that the historical Apion ever wrote an Orphic Cosmogony.

${ }^{21}$ We can find an Orphic Cosmogony in both Pseudo-Clementine traditions: Hom. 6.3.4-10 and Rec. 10.17.2-20.1 and 30. The version of the Recognitions seems to be more influenced by Hesiod's Theogony where Chaos acts as the first principle. There has already been a lot of discussion about the relationship between the Homilistic version and that of the Recognitions. I refer to: Heintze 1914, 14-23, Strecker 1958, 79-87, Van Amersfoort 1981, 28 30; Roig Lanzillotta 2010, 130-137.

${ }^{22}$ In his Dubitationes et Solutiones de Primis Principiis, the fifth/sixth-century Neoplatonist Damascius made a distinction between three versions (Galpérine (ed.), Damascius 1987, 630-633): a Rhapsodic version, an Orphic Cosmogony attributed to Hieronymus and Hellanicus, and one preserved by Eudemus, pupil of Aristotle. See for an updated account of all Orphic testimonies: Bernabé 2004. Although Otto Gruppe (1887, §47) classified an Orphic Cosmogony of 'Clemens Romanus' (by which he meant the version in the PseudoClementine Recognitions) as one of the variants, it has never been considered as a fully autonomous version. Researchers such as Otto Kern (1922, §55-56), Luc Brisson (1990, 2902-2914), Ezio Albrile (2000, 55-85, see 65) point to the affinities of the Pseudo-Clementine variant with the tradition of Hieronymus and Hellanicus. On the other hand, Lautaro Roig Lanzillotta (2010, 115-141) and Alberto Bernabé (2004, 2.124-126), are more inclined to align the Homilistic variant (and that of the Recognitions) with the Rhapsodic Orphic tradition. Jacobus Van Amersfoort (1981, 22-25) links it both to the Rhapsodic tradition and to the tradition of Hieronymus and Hellanicus. According to Fabienne Jourdan (2010-2011, 4-5), the Pseudo-Clementine version is an earlier Rhapsodic representative than the version known to Proclus and Damascius, even earlier than the tradition of 
insight into the role of this unique Orphic Cosmogonical version in the light of the disputes between Clement and Appion, which is also a reason why the narrative and rhetorical richness of this Homilistic passage is underexposed. By analysing the structure of Hom. 6, we can explain several unique features of this Homilistic Orphic Cosmogony that cannot be explained as coming from a certain cosmogonical tradition. Therefore, we have to look to the general structure of Hom. 6. Remarkably, the disputes on the third day have a parallel, ring structure, which can be divided into five main parts.

I. Start: Clement meets Appion. The latter gives a list of Greek myths and rejects each one of them (6.1-2).

A. In doing so, he criticises his opponent's hermeneutics of reading myths in a literal way.

II. Appion then gives an allegorical explanation (the Orphic Cosmogony) of several of these enlisted myths (6.3-10)

III. Turning point: Appion does not finish his allegorical explanation. Clement in his turn replies he already knows what is coming and takes the floor (6.11).

IV. Clement finishes the allegorical explanation of Appion on the basis of the list of the rejected myths (6.12-23).

A. While finishing this explanation, Clement is criticising the allegorical hermeneutics.

V. End: Clement ends with a list of features of God and rejects each one of them (6.24-25). Subsequently, Peter arrives.

These five parts are construed in a parallel structure with parts (I), (I.A) and (II) respectively concentrically parallelled to (V), (IV.A) and (IV) with part (III) as the turning point of the whole construction. We can also notice that the roles of Appion and Clement are mirrored. The structure of Appion's list of rejected myths (I) has a key role in the further development of the discussion. Both Appion and Clement make use of Appion's list of Greek myths (6.1-2) in order to structure their dissertations (parts II and IV) by following and filling in each myth with a particular allegorical explanation. I have made that clear in the scheme below to which I will refer further in the rest of this article. My point here will be that Clement consciously uses Appion's structure in comparison to Appion's own rhetorical use of it. The way of using rhetoric nicely fits in with the structure itself. Appion will give an allegorical dissertation about some of the rejected myths

Hieronymus and Hellanicus. Thus, she gives a big authority to the Clementine version. See also Jourdan's work for more information about the role of Orphic Cosmogonies in Christian discourses. 
which he will analyse in a natural-philosophical and etymological way by referring to an Orphic Cosmogony (part II). Clement will change the way of offering an explanation. After the turning point (III), when Clement finishes the allegorical explanation of Appion (part IV), he is in fact behaving himself as a pseudo-Appion. He says that he knows the further arguments of Appion and sums them up as Appion would have told them according to Clement in the context of explaining myths in an allegorical (and etymological) way. However, Clement is changing the focus. In contrast to Appion's physical-philosophical explanation of the myths, Clement will focus on the moral-epistemological way. This is not neutral of course because Clement is already preparing his own criticism of Appion's allegorical hermeneutics (part IV.A) by focusing on the lack of morality and of truth in the opponent's culture.

\begin{tabular}{|c|c|c|c|}
\hline & Myth & $\begin{array}{l}\text { Appion's rejection of a } \\
\text { literal reading of Greek } \\
\text { myths (part I) }\end{array}$ & $\begin{array}{l}\text { Allegorical explanation } \\
\text { by Appion - Clement } \\
\text { (part II and IV) }\end{array}$ \\
\hline 1 & $\begin{array}{l}\text { Uranus and Gaia and the chains of } \\
\text { Kronos }\end{array}$ & 6.2 .2 & Clement: 6.13 .1 \\
\hline 2 & Motif of castration & $6.2 .2-3$ & Clement: 6.13 .1 \\
\hline 3 & Aphrodite's birth & 6.2 .3 & Clement: 6.13 .2 \\
\hline 4 & $\begin{array}{l}\text { Kronos' union with Rhea and Kro- } \\
\text { nos' devouring of Poseidon and } \\
\text { Pluto (and a stone instead of Zeus) }\end{array}$ & $6.2 .3-4$ & Appion: $6.5 .1-6.6 .2$ \\
\hline 5 & $\begin{array}{l}\text { Kronos' throwing up of Pluto and } \\
\text { Poseidon (and the stone) }\end{array}$ & $6.2 .4-5$ & Appion: 6.6.3-6.7.4 \\
\hline 6 & Zeus is the new heir & $6.2 .5-6$ & Appion: 6.6.3-6.7.4 \\
\hline 7 & Zeus' sexual adventures & $6.2 .6-7$ & Appion: $6.10 .2-3$ \\
\hline 8 & Athena's birth (out of Zeus' head) & 6.2 .7 & Appion: $6.7 .5-6.8$ \\
\hline 9 & $\begin{array}{l}\text { Birth of Dionysus (out of Zeus' } \\
\text { thigh) }\end{array}$ & 6.2 .8 & Appion: 6.9 .3 \\
\hline 10 & $\begin{array}{l}\text { Marriage of Peleus and Thetis and } \\
\text { the subsequent Judgment of Paris }\end{array}$ & $6.2 .8-10$ & Clement: $6.14 .1-6.15 .4$ \\
\hline 11 & $\begin{array}{l}\text { Helen as the 'reward' of the Judg- } \\
\text { ment }\end{array}$ & $6.2 .11-12$ & Clement: 6.16 \\
\hline
\end{tabular}




\section{Appion's 'negated mythology'}

and his criticism of Clement's hermeneutics (6.1-2: Part I and I.A)

\section{Appion the Sophist and his claim of 'truth'}

On the third and final day, Clement arrives at the appointed place and meets Appion who is joined by a large number of so-called 'men of paideia' (' $\tau \tilde{\omega} \nu \dot{\varepsilon} \kappa$ $\pi \alpha 1 \delta \varepsilon i \alpha \varsigma \alpha \dot{\alpha} v \delta \rho \tilde{\omega} v$ '; Hom. 6.1.1) and who himself was introduced as a grammarian

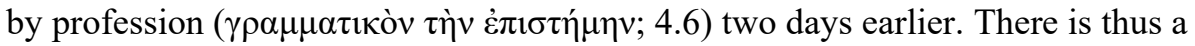
strong representation of Greek paideia. The two, Appion and Clement, continue their rhetorical jousting game of the previous days. Appion immediately takes the floor and wants to present an allegorical interpretation of the Greek myths as a counterweight to the proposed hermeneutics of Clement. On the previous days, Clement had been attacking the unacceptable immorality of Greek paideia, in particular the myths which he had been approaching in a very literal way. For example, Clement discussed and refuted Appion's so-called 'ode to adultery' on the previous day, in which Appion had given a list of myths about gods (in particular Zeus) who take on a different shape in order to commit adultery with their sisters, mortal women, and even boys (5.11.3-12). This list was meant to convince the Roman matrona, with whom the young Clement was supposed to be in love (according to Appion), to commit adultery: if gods do it, why should men not do it. Appion, however, feeling threatened by Clement's literal hermeneutics of the previous day and the claim that Greek paideia is immoral, argues that his encomium was nothing more than a fiction, and that the truth is in fact hidden:

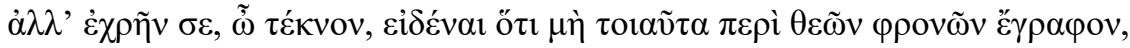

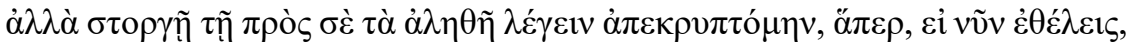

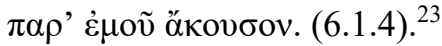

Appion and truth, however, are not a real match. At the end of his encomium, Appion wrote that he was speaking the truth and that he himself was the hierophant in the mysteries of love and would teach his disciples the truth (5.19). Moreover, the encomium and its 'truth' were only a rhetorical game to help the young Clement. In this way, Appion acts as a 'Gorgias'. It is only a literary game as

\footnotetext{
23 'But, my son, you ought to have known that I was not in earnest when I wrote such things about the gods, but was concealing the truth, from my love to you. That truth, however, if it so pleases you, you may hear from me now'; English translation: Riddle and Smith 20044, 364-620, see 456.
} 
Gorgias concluded his own encomium of Helen of Troy: 'ćuòv $\delta \dot{\varepsilon} \pi \alpha$ íyviov'. ${ }^{24}$ Appion is thus not only a grammarian, but also a Sophist ${ }^{25}$ who has, according to Clement in a kind of Platonic fashion, no right, nor intention to possess the 'real truth'.

\section{Appion the philosophical, allegorical interpreter}

Appion, however, gives his 'true' truth the shape of a physical ${ }^{26}$-philosophical allegorical ${ }^{27}$ explanation. First, he gives a list of several Greek myths, and rejects each one of them (see scheme). I call this part (I) the 'negated mythology', which will be construed in parallel with what we can call the 'apophatic theology' of Clement at the end of the disputes (v). ${ }^{28}$ The list of rejected myths starts with the story of Uranus and his mother Gaia and ends with Paris' Judgment, with Helen as his 'reward'. This list of rejected myths is a clear example of inductive argumentation which suits Appion's argumentation as he used it in his encomium (discussed on the previous day). In this encomium, he summed up several lists of gods and their affairs with women and boys, as well as a list of philosophers who supported adultery (5.11.3-18). Based on his list of negated myths, Appion wants to demonstrate his 'true' allegorical interpretation of each one of them. He calls it

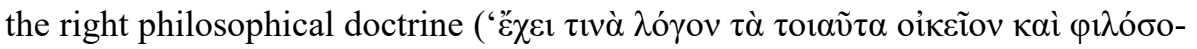
pov ...', 6.2.12) as an answer to Clement's literal reading method. In the Homilies, however, the allegorical hermeneutics, linked to the opponents, are not received well because they are considered as wicked features of the pagan

${ }^{24}$ This is not just a game of course. It shows how the Sophistic movement, the First Sophistic in the case of Gorgias, but also the later Second Sophistic, was reflecting on the power of the word, or in Greek, logos; MacDowell (ed.), Gorgias 2005, 16-17.

${ }^{25}$ I already referred to the Sophistic context of an encomium.

${ }^{26}$ Terms related to $\varphi v ́ \sigma i \varsigma$ frequently occur in Appion's explanation who speaks about

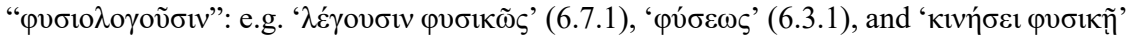
(6.4.2).

${ }^{27}$ See for the general role of allegorical readings in and according to Christian discourses: Pépin 1958, think of Justin Martyr's 1 Apologia 23.3 or 2 Apologia 8.1, or Origen's Contra Celsum IV. One of the questions in the general discourse was if the Scriptures could be read allegorically (e.g. contra Diodorus of Tarsus or Theodorus of Mopsuestia). Here, in these Homilistic disputes, we have to deal with the question if myths can be read allegorically.

${ }^{28}$ Apophatic language is not uncommon in the Clementines. See the doctoral thesis of Päivi Vähäkangas who compares the Recognitions with the gnostic writing Eugnostus, e.g. the apophatic language in both works (2012, 127-130). 
opponents. ${ }^{29}$ For example, in Egyptian polytheism, the practise of honouring all sorts of beings, going from onions to farts is stressed in the Homilies. ${ }^{30}$ Ashamed by this 'divine digestion', people wanted to defend these cults and accompanying myths by using allegories (10.18.4-5). About the preceptor of Appion, Simon Magus, it is even said that he used classical paideia and the technique of allegorisation in order to deceive people (2.25.3). ${ }^{31}$ In this way, due to the negative connotation of allegorical hermeneutics with Simon Magus, Appion's dissertation takes a false start.

\section{Appion's further rhetorical-Sophistic persona and his allegorical explanation (6.3-10: Part II)}

Appion's actual allegorical explanation begins with a reference to a time of chaos and a mixture of unseparated and disordered elements (6.3), quoting two influential authors: Homer and Hesiod. In Homer, on the one hand, the theory is found that everything has its origin from and can return to the humid and earthly substance, which is the same as Chaos according to this Homilistic passage (Iliad, 7.99). Hesiod, in turn, also says that Chaos was the first principle (Theogony, 116). Quoting and referring to authors is another inductive argumentative technique, which again typifies Appion in the Homilies as a (Sophistic) $)^{32}$ philologist and grammarian, and this especially helps him in his quarrels and discussions. ${ }^{33}$ This characterisation shows his status of a pepaideumenos, and Appion is, therefore, the ideal opponent to Clement when discussing Greek paideia. This is in line with what we know from the historical Apion. The historical Apion was known for his

${ }^{29}$ See also Rec. X.42.1-4 where the allegorical method is seen as something 'pagan'. See for a more elaborate discussion of the allegorical method in the Homilies, Carlson 2013, chapter 1 .

${ }^{30}$ Lucian also mocks the Egyptians and their gods, for example in his Zeus Rants, because Egyptians even adore onions (§42). See also Juvenal, Satires XV, 1-13. This kind of mockery then was used by Christian authors.

${ }^{31}$ This representation of allegories as rhetorical or rationalising techniques as is the case with Simon, Appion and Egyptian polytheism, is also described in other Christian testimonies, such as De errore profanarum religionum (2.6) of Julius Firmicus Maternus (early fourth century).

32 Think of the character Phaedrus in Plato's Symposium who refers (incorrectly) to several authors and uses many examples.

${ }^{33}$ See for references of the 'historical' Apion as a grammarian: Bremmer 2010, 84-86, see also Côté 2015, 377-378. This link is relevant and consistent with the act of explaining Greek myths and of writing an encomium, such as Appion is doing. 
knowledge of Homer's works. According to Seneca (Epistula 88), Apion was acclaimed a Homerid ('in nomen Homeri') due to the many travels he made through Greece during which he gave many lectures on the Homeric corpus. We moreover have some excerpts of Glōssai Hōmèrikai, ${ }^{34}$ attributed to the historical Apion. This also helps us to understand the aforementioned Hesiodic and especially Homeric references and quotes in these Pseudo-Clementine disputes, but also other passages such as in Hom. 5.12 which refers to Iliad 1.544. These Homilistic passages are, not accidentally, attributed to Appion. Moreover, an interesting copy of an inscription attributed to Apion has been discovered recently, ${ }^{35}$ which honorates Apion as a poetic victor. It enlists all the privileges and honours conferred on him for his victories in various poetic contests. ${ }^{36}$ The historical Apion, just as the Homilistic character, is thus a man of Greek paideia with many Sophistic pretentions since Sophists typically knew Homer and many other classical authors, but also since we nowadays know that several Sophists received honorary statues. ${ }^{37}$

Appion's physical-philosophical explanation can be divided into three parts. First, there is the period of chaos and disorder (6.3-4); then, there is a first level of order and production of the egg ${ }^{38}$ out of which Phanes appears (6.5-6). Third, the largest part is a discussion of the further generations of elements and the true nature of the gods (6.6-10). Appion uses in this last and largest segment a selection of the structure of his 'negated mythology', namely numbers 4 to 9: the myths

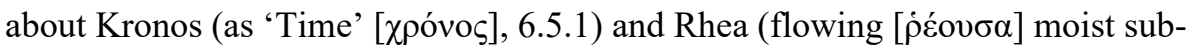
stance), Kronos' devouring (Time lets matter sink) of his children Pluto (heavy,

\footnotetext{
${ }^{34}$ See also note 46.

${ }^{35}$ See Benaissa 2014, 125-138.

${ }^{36}$ For example, this copy mentions statues which were erected for Apion in Actium, Olympia, Delphi, the Isthmus, and Nemea, so the five agonistic centres. Moreover, ' $[\mathrm{h}]$ is native city, which is not named [possibly Alexandria], honours him with the standard privileges and awards accorded to victors in great games: triumphal entrance into the city in a white four-horse chariot; meals in the prytaneum; a golden crown(?); a gilded crown said to be 'of the periodos'; and no doubt other awards now lost in the large lacunae following line 10.' (Benaissa 2014, 125, 128). The 'periodos' of Apion as poet could be connected with Seneca's statement that Apion made many travels through Greece and that he was called 'in nomen Homeri', but this can also be perfectly connected with Apion as scholar/grammaticus since that epithet was also bestowed on other scholars, see Benaissa 2014, 126.

${ }^{37}$ See the contribution of Ewen Bowie (2004) in B.E. Borg, Paideia: The World of the Second Sophistic, Berlin: Walter de Gruyter, 65-84.

${ }^{38}$ The egg is represented in the Homilies as well as in the Recognitions as a 'globe' which will be broken (Hom. 6.4.3; 12.2 and Rec. X.17.3). Only in the Homilies, the egg is seen as a 'bubble' (6.4.3), while the Recognitions use this term for 'Pluto', the distinct entity that falls down after being hardened by the cold/ice, see Jones 2019, 74.
} 
abundant mass: $\pi \mathrm{o} \lambda \grave{v}[\ldots] \pi \lambda \tilde{\eta} \theta \mathrm{o} \varsigma{ }^{39}$ and Poseidon, ${ }^{40}$ but not Zeus ${ }^{41}$ (his boiling

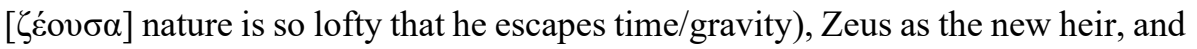
his sexual adventures and his many children. This exposition is combined with the Orphic tradition: Phanes appeared ( $\varphi \alpha v \varepsilon \dot{v} \tau o \zeta, 6.5 .4)$ out of an egg formed by Kronos and Rhea, the other residues in the egg are then Pluto and Poseidon. This Phanes, who illuminates the universe and gives everything its harmony, is combined with the element of fire as Zeus is. ${ }^{42}$ This way, Appion lets these etymological interventions of the enlisted Greek myths fit in an etymological-Orphico-allegorical dissertation and vice versa. This partly explains the uniqueness of this Orphic Cosmogonical version. Appion also explains some of his other rejected myths. Metis is pneuma and produced, after being consumed by Zeus/heat, the continuous palpitation $\left(\pi \alpha \lambda \mu\right.$ óv) and intelligence 'Pallas' ${ }^{43}$ This Pallas is the artistic wisdom with which the ethereal artist gave order to the whole world. ${ }^{44}$ From

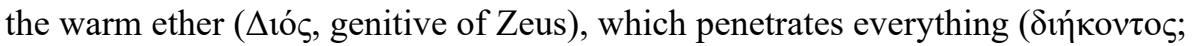
6.8.2), the tempered and fertile air/climate which is Hera (etymologically linked to $\dot{\alpha} \eta \dot{\rho} \rho$ ) comes to earth. ${ }^{45}$ Athena is infertile - which is linked to her state of being a virgin - because of the excessive heat of Zeus. Artemis, the lowest airflow, is also a virgin because of the excessive cold. Dionysus in his turn stands for the high and low currents of air (because he flies from high to low as a symbol of drunkenness).

${ }^{39}$ Cf. Rec. X.18.5; 19.2 for Pluto as first child. For his descending because of his weight: Rec. X.32.2. For other etymological explanations of Pluto/Hades, see e.g. Cornutus' Epidrome $\$ 5$ (Hades as not to be seen, or as the one who does not pleases us or Pluto as the future owner of our souls).

${ }^{40}$ Cf. Rec. X.19.3 for Poseidon as second child. For Poseidon flowing above Pluto: cf. Rec. X.32.3-4.

${ }^{41}$ Cf. Rec. X.19.4. For Zeus' ascending as 'fire': cf. Rec. X.32.5-6. For other etymological explanations of Zeus, see e.g. again Cornutus $\$ 3$ (as 'Life', 'through', or to 'bedew').

${ }^{42}$ According to Le Boulluec, who refers to Brisson, this Homilistic element is influenced by Stoicism, which supported the idea of the primordial role of fire. Brisson 1990, 2911, see for Le Boulluec: Geoltrain and Kaestli 2005, note 5.4. Interestingly, Hippolytus writes in his Refutatio Omnium Haeresium that Simon Magus also stated that fire was the primordial principle (6.11.1-19). The association between Phanes and fire can be found in the Homilies, but not in the Recognitions. According to Jones $(2019,75)$, this is a reduplication of Zeus 'who, in the documented Basic Writing, is identified with fire and ascends' and is added by the Homilist. In this way, Jones supposes that the Recognitions preserved the more original Orphic account.

${ }^{43}$ See already Plato's Cratylus 407b; Cornutus links it with being 'young' (Epidrome \$20). Sometimes pallein is linked with Apollo (vibrations of the rays), see Pépin 1958, 398n 26.

${ }^{44}$ Cf. Rec. X.33.2-3.

45 That Hera is situated under the pure ether, is explained by the gender aspect: as a woman (being a sister and a wife), she is inferior. 
The following gods are peculiar. First of all, they are not mentioned in the list of Appion (I). Second, these gods are all connected with ancient mystery cults. The Egyptian god, Osiris stands for the water under the earth and for all the streams scattered over the earth (боүколтó $\mu \varepsilon v o v$, 'cut into pieces'), but all that water remains united by nature. Adonis stands for the seasonal fruits, Aphrodite for sexual union and reproduction, Demeter for the earth, Korè for seeds and (again) Dionysus sometimes for vines. Mithras, who is also called Appolo (who is the sun that makes rotations, coming from $\pi \varepsilon \rho 1 \pi 0 \lambda$ oṽv $\tau \alpha$ ) completes an annual cycle. By involving these gods the pantheon is expanded with gods of mystery cults. The status of some of these gods is also attacked in the Recognitions (X.25), but for example Mithras is not mentioned there and moreover, the other gods mentioned are not grouped together as they are in the Homilies. This means that the editor of the Homilies clearly also wanted to target the gods of the mystery cults. ${ }^{46}$

In addition to the physical core of the allegorical explanation, the etymologies are important as has become clear. ${ }^{47}$ This wordloving or 'philological' aspect corresponds to the Homilistic characterisation of Appion. ${ }^{48}$ Besides the allegorical and physical core of the explanation of Appion, we also notice the emphasis on a

46 This could also mean that this particular piece of text originated from an area where Mithras and other gods, linked with mystery cults, were popular. Mithras was especially popular in the Western part of the Roman empire and became popular in the second century. See Burkert 1987, 2; see also: Cumont, Van Haeperen, Bonnet, 2009, chapter 6: La Perse. The name of Mithras could also be an interpolation since it does not appear in the Recognitions nor the Syriac versions, but it still is noteworthy to see how these mystery cult-gods are grouped together in the Homilies (maybe due to influence of Apologetical literature, see e.g. Tatian's Oratio ad Graecos 28-29.1).

47 These etymological and linguistic games could, according to Pépin (1958, 344n178 and 398), go back to the Stoics. The link with Stoicism and the etymological explanation of names of Greek gods can also be found in texts of early Christian authors such as Athenagoras (Legatio §6) and Clement of Alexandria (Protrepticos, I.18.1).

${ }^{48}$ The 'historical' Apion was also linked to etymological games. For example, Flavius Josephus refers to Apion's Aegyptiaca in which Apion claims that the Jews, during their exodus, had to stop on the seventh day because they suffered from swellings in their groin area. These swellings were called 'sabbo' in Egypt, which led to the name of the Jewish rest day: sabbaton. Josephus' Contra Apionem 2.21; See also Dillery 2003, 387-388. There are also some examples preserved from his work on Homer (Glōssai Hōmerikai). Apollonius Sophista (who wrote near the end of the $1^{\text {st }}$ century a Homeric glossary) preserved some of Apion's etymological explanations. Bekker, I. (ed.), Apollonius Sophista 1833. See also: van der Horst 2002, 215-217. Dillery $(2003,389)$ states in line with M.W. Haslam that these etymological explanations show how Apion is 'specialised in contriving novel etymologies for much-discussed words, almost as if to show it is a game that anyone can play.' Haslam 1994, 28n83. This is, of course, interesting in line with Appion's characterisation in the Homilies. 
philosophical character. Appion already mentioned that his allegorical explanation would be philosophical (6.2.12). This fits the philosophical references in his encomium of the previous day. According to Clement, the Roman matrona, for whom the encomium was written, was interested in philosophy, which entailed that Appion had to pay attention to this. At least, that was what Clement had told Appion. And indeed, Appion referred to several philosophers in his encomium who have defended adultery (5.18). One of the examples is the wisest of them all, Socrates, who taught that, in a well-regulated state, women should be common property. ${ }^{49}$

\section{The turning point and the shift towards}

Clement's moral-epistemological interpretation (6.11-23: Parts III and IV)

\section{Clement's rhetorical abilities and different personae}

During Appion's explanation, Clement is lost in thoughts, which does not escape Appion's attention (6.11). The latter asks why he should continue if Clement is not paying attention anymore. Clement brags he already knows this allegorical dissertation, and he even wants to finish it where Appion had stopped before. Here we have to deal with the turning point in the discussion of the third day. It is peculiar that Appion's allegorical explanation is not over yet and that Clement finishes this explanation. He fills in the rest of the structure of the 'negated mythology' as a pseudo-Appion, taking up the persona and the accompanying rhetorical discourse of Appion himself. This is characteristic of the rhetorical processes of anaskeue and kataskeue. ${ }^{50}$ Even though Clement rejects Greek education

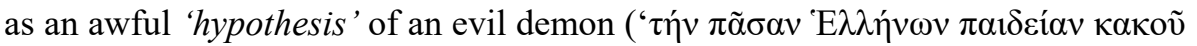

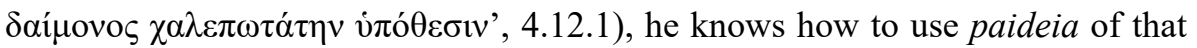
same classical world, and, in particular, those rhetorical principles of anaskeue

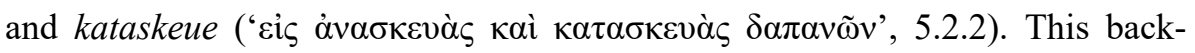
ground allows him to argue and to reject the different propositions as he has been taught in Greek education. He is even familiar with Greek paideia to such an extent that he knows what Appion's arguments will be (6.11) which also explains the possibility of such a narrative structure: Clement is able to finish Appion's

49 This is indeed mentioned in Plato's Laws 5.739c, Aristotle's Politica 1264b25, and in Diogenes Laërtius' Lives of Eminent Philosophers 2.5.26. See also the parodic description of sex in plain sight and the sharing of women on the Island of the Blessed in Lucian's True History where the 'Blessed' are even 'more Platonic' than Plato himself (II, 19: ' $\alpha \lambda \lambda \lambda$ ' घi்ì

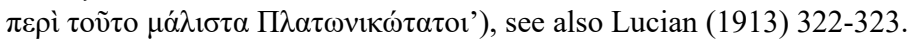

${ }^{50}$ See for more information on these rhetorical principles: Webb 2001, 289-316. 
argumentation (part IV) and, thereafter, to reject it (part IV.A). It is interesting to see how the topic of Greek education is being discussed during these three days of disputes, while the disputes themselves are a perfect testimony of this particular education. Both opponents know how to use their rhetorical background. Clement takes on the rhetorical persona of Appion ${ }^{51}$ and, in fact, performs a prosopopoeia and an ethopoeia by acting as Appion. The remarkable thing compared to this passage is that this rhetorical process of the prosopopoeia usually concerns absent people. Here, Clement uses the rhetorical persona of Appion for finishing Appion's discourse, by using paradeigmata, ${ }^{52}$ etymological explanations, and allegorical explanations, but he will, as I argue, playfully and effectively change this in an attack against Appion. His explanation will not be a physical-philosophical one as Appion's, but moral-epistemological. He will use this change of focus for his own criticism of Appion's allegorical hermeneutics in part IV.A of Hom. 6, which is parallel to Appion's criticism of Clement's literal hermeneutics in part I.A. Therefore, Clement will be the one who determines the rest of the disputes, doing this in a clever rhetorical way which is more than just an educational example of anaskeue, kataskeue and ethopoeia.

\section{Clement's shift towards a moral-epistemological interpretation}

Clement first gives a summary of what Appion has already said (6.11.3-6.12). He then continues with some allegorical explanations he has heard from others: the chains of Kronos stand for the meeting between heaven (oủpavós) and earth ( $\gamma \alpha i i \alpha)$ and the cutting away of Kronos' genitals stands for the separation of the elements. 'Kronos/Time' is not able to produce anything anymore but his offspring is. Aphrodite comes from the depths as fertile substance. Mixed with pneuma, she longs for sexual union and perfects the beauty of the world. In this way, Clement fills in the first elements of Appion's 'negated mythology' which were neglected by Appion in his allegorical explanation (namely the chains of Kronos, his castration and Aphrodite's birth: parts 1-3 in the scheme). Clement then continues with the wedding banquet of Thetis and Peleus (6.14), which was the penultimate section of Appion's 'negated mythology', and which was also neglected by Appion in his allegorical explanation (see parts 10-11). The banquet represents the world, the

${ }^{51}$ This echoes the theme of shapeshifting in myths (Zeus' changing of forms in order to commit adultery) and in the Homilistic narrative (at the end of the story Simon changes faces with Clement's father, Faustus: Hom. 20.12).

${ }^{52}$ Clement also displayed his ability to use inductive argumentation on the second day (5.23) in a letter as an answer to the encomium. Nota bene, he also combined it with a performance of ethopoeia because he deceived Appion by presenting this letter as written by the 'Roman matrona'. 
twelve gods stand for the zodiac, Prometheus for providence $(\pi \rho 0 \mu \eta \dot{\eta} \theta \varepsilon 1 \alpha)$, through which everything is created, Peleus is the clay $(\pi \eta \lambda \hat{o} \varsigma)$, provided for the production of humans, and the Nereid, Thetis, stands for water. Achilles stands for the first man, modelled with these elements (and thus not engendered by them) in his mature form meaning that he had never put his lips $(\chi \varepsilon i ́ \lambda \eta)$ on a breast, which is the etymological explanation of 'Achilles' (a-privatum and $\chi \varepsilon i \hat{\lambda} \eta$ / breasts). At the peak of his life, he died by an arrow piercing his heel. Moreover, this arrow was poisoned with a snake's venom. This happened when Achilles was longing for Polyxena, whose name is explained as 'that which is very strange ( $\xi \dot{\varepsilon} \vee 0 \varsigma$ ) to the truth'.

Clement/pseudo-Appion is changing the focus here to the choice of wrong knowledge, in line with Achilles and his choice for Polyxena. According to Nesterova, the element of the snake indicates a Jewish-Christian influence, in particular, of the negative representation of the snake as lust for knowledge as can be found in Genesis 3:15-16. ${ }^{53}$ It is, however, not only an agreement with the Genesis story that makes this interesting. It is Clement's rhetorical use of this in order to let it fit in his moral-epistemological explanation. As sexually desired object and as a mythological and allegorical subject, Polyxena appears as truth-breaking and destructive to humans. Achilles makes the wrong choice and therefore this leads to his downfall. However, that same Achilles, seen as the first man, is also connected with the Genesis story as an 'Adam', and in this way, Polyxena functions as an 'Eve'. This does not seem to be just an innocent mixing of traditions. As I stated before, Clement is changing the method of the allegorical explanation into a moral-epistemological one. These two themes of morality and epistemology are two key themes in Clement's criticism in part IV.A. The next example of a moral and epistemological choice is Paris. In the story of the Judgment of Paris, Hera stands for dignity, Athena for courage, Aphrodite for pleasure, Hermes for her-

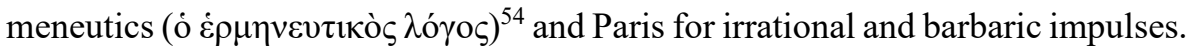
At the peak of his life, reason, the shepherd of the soul, is barbaric, he neglects

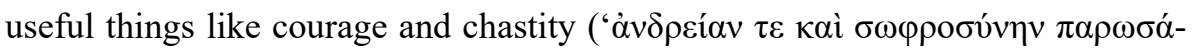
$\left.\mu \varepsilon v o \varsigma^{\prime}, 6.15 .3\right)$ and chooses only pleasure and lust. In this way, he prepares his own downfall and that of his beloved ones through his choice. This example of Paris reinforces the previous one of Polyxena and Achilles, and shows the moralepistemological character of Clement's explanation as a 'pseudo-Appion'. Both Paris and Achilles deal with the downfall due to wrong knowledge linked to a

\footnotetext{
${ }^{53}$ Nesterova 2008, 397- 408, see 405.

${ }^{54}$ See also e.g. Cornutus (Epidrome, §16). A similar, later connection between Hermes and the hermeneutics can be found in Johannes Diaconus' commentary on Hesiod's Theogony 943; See Harris 1921, 138-139.
} 
woman. In the enumeration of the characters of the Judgment of Paris, and in fact also of the post-Homeric cosmos (Achilles and Polyxena), a very important individual is missing, especially when it comes to adultery and suffering: Helen. This is even more striking because Helen was the last element in Appion's 'negated mythology' (see scheme above), and because she plays a major role in the rest of the Homilies. However, Clement conceals her here and, in that way, that is remarkable.

In the Homilies, Helen is strongly connected with false and deceptive knowledge. Simon Magus stated that Helen, the famous Helen of Troy, descended from heaven to walk beside him as the personification of 'his' truth/wisdom ('бopíav'; 2.25). ${ }^{55}$ However, this truth is undermined. Helen as a symbol of 'truth' is just a mythological symbol of deceptive, false knowledge, as a result of the indication that Simon deceives people with his allegories of Greek myths among which the myth about Helen as is earlier described in the Homilies (2.25.3): ' $\pi \lambda \eta \dot{\eta} v$

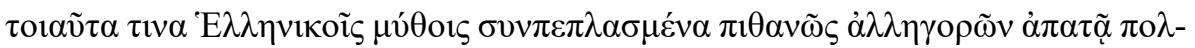
$\lambda$ ov́ $\varsigma{ }^{56}$ The epistemological elusivity surrounding Helen is combined with adultery. Helen was already implicitly attacked by Clement on the first day of the disputes with Appion by stating that adultery is the cause of destructive and bloody wars (4.22). Therefore, when Appion ended his negated mythology, at the beginning of the third day, denying the mythological background of Helen, he wanted to 'save' Helen as the image of truth of his friend, Simon Magus, and was preparing for a climax of his allegorical dissertation. Clement, however, dedicates the conclusion of his explanation as pseudo-Appion, not to Helen, but to Heracles. First, we could suppose that the Homilist did not feel obliged to deal again with Helen and her role as 'wisdom' in relation to Simon. However, from my point of view, Clement playfully undermines the position of Helen and Simon, and in that way, of Appion too. This depiction of Helen as a symbol of false and deceptive knowledge is in line with the previous moral and epistemological examples, again a connection between a woman and a particular kind of knowledge, and the one who longs for her is - meaningfully - irrational and leads to his downfall, just as Achilles already had his downfall. In this way, the Homilistic world of Simon and Helen is under fire. Their truth is irrational and in comparison with Paris who undermines his relatives by his choice of Helen, it does not look too well for Appion, being Simon's relative. The attack against 'them', the opponents, becomes

${ }^{55}$ Helen as a part of Simon's doctrinal system, and the rejection of it, can already be found in the work of the Christian apologetical author Irenaeus of Lyon (Adversus Haereses, 1.23.2).

56 'Moreover, by convincingly explaining certain things of this sort, made up from Grecian myths, he [Simon] deceives many.' Riddle and Smith 20044, 397. 
even stronger when we notice that Achilles, who resembles Adam as has been mentioned before, is a contrasting image of Adam in the rest of the Homilies. Whereas Achilles chose the wrong knowledge in the form of a woman, Adam is generally, in the Homilies, considered as blameless and not a transgressor: he did not follow Eve who is fully responsible for the $\sin (2.52 .2 ; 3.18 .1)$. This way, the 'Greek' first man failed, the opponent's world has chosen the wrong knowledge/ woman. Hermes, alias the hermeneutics, has been put in jeopardy by that barbarity and irrationality and Clement will make clear after his role as pseudo-Appion that these hermeneutics have been compromised by the incoherence of the Greek myths and irreverence of the authors of these perverse myths. Clement lets these two arguments follow immediately after pseudo-Appion's last example, which will substantiate his criticism. Even though Heracles does not appear in the 'negated mythology', he is still the final piece and that is striking.

It does not seem innocent that Clement attacks Heracles in Tyre, since he was worshipped there. ${ }^{57}$ This will have stimulated the choice of this character, but this will not be the only reason. Clement, as pseudo-Appion, tells his audience that Heracles killed the serpent who was lord and guardian of wealth, but above all, Heracles himself was an example for philosophers and a friend of wisdom, free from malice, wandering across the world in all directions, visiting the souls and bringing every one he had met to the right path, for instance, people who are like bold lions, ferocious boars, hydras ... All his works are, in fact, hidden allusions to the 'intellectual virtue' ( $\operatorname{vo\varepsilon \rho \tilde {\alpha }\varsigma } \dot{\alpha} \rho \varepsilon \tau \tilde{\eta} \varsigma)$. Heracles is thus the personification of

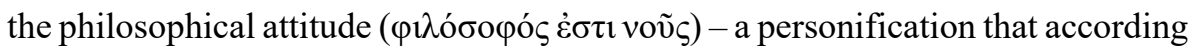
to Pépin goes back to the Cynics, and in fact also the Sophists such as Prodikos ${ }^{58}$ - and thus forms the counter-example of the aforementioned Achilles and Paris who made the wrong moral-epistemological choice. The killing of the serpent symbolises the 'killing' of untruthful and deceptive knowledge and the end of the desire for wealth. With this allegorical explanation, Clement seems to have come to terms with the false knowledge and with mythological figures such as Achilles

57 The link between Heracles and Tyre is explicitly stated in Rec. X.24, but not in the Homilies. Other ancient literary witnesses of the 'Tyrian Heracles' are Herodotus (Historiae 2.44) and Josephus (Antiquities 8.5.3).

${ }^{58}$ We can find Heracles as the philosopher or the one who introduced philosophy in the Hesperian regions in the extant fragments of Herodorus, a mythographer from 4th c. B.C.E. who was familiar with allegories (fragment 14; Trzaskoma, Smith, and Brunet (eds.) 2004, 121-122); This image of the philosophical Heracles also occurs in Xenophon's Memorabilia, where an anecdote by the Sophist Prodikos about Heracles is discussed. Heracles had to make a choice between the way of Virtue and that of Vice (Memorabilia, II.1.21). See also Cornutus (\$31) and Heracles as universal reason. See also Pépin 1958, 106; 400 and Brisson 1990, 2913. See also Lucian's Hermotimos $\$ 7$ where Heracles is described as the true philosopher. 
and Paris. The example of Heracles seems to be completely positive according to

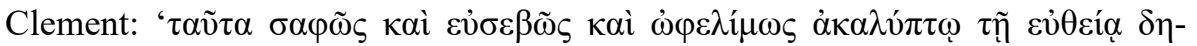

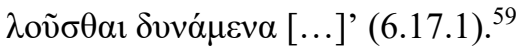

\section{Clement's criticism of the allegorical hermeneutics (Part IV.A)}

However, this example of Heracles nicely fits in with the following criticism of Clement. After this latest example, he leaves his rhetorical persona as pseudoAppion behind. Now it is Clement himself, without further ado, who is taking the floor. Does his last example of Heracles mean that Clement is suddenly defending the truth behind the myths? Certainly not. We have to pay attention to three pieces of information. First, Clement has only heard of these explanations from someone unknown (6.11), so he is able to use these explanations in a clever way but manages to keep a certain distance. Secondly, he finishes the dissertation of Appion, not his own. Therefore, Clement is a real master of Greek paideia as we saw with the rhetorical principles of anaskeue and kataskeue, prosopopoeia, and ethopoeia. As has been made clear, Clement is also skilled in allegorical and etymological hermeneutics. It is worth noting to see how Clement uses the same hermeneutics as Appion against Appion himself and fulfills both roles in the rhetorical framework of anaskeue and kataskeue in a very clever way. Thirdly, Clement already called Heracles an example of adultery (4.15, first day of the disputes) and Appion, in his encomium, wrote that this same Heracles was the bastard child of an adulterous Zeus and that Heracles himself had seven relationships with boys. So, in fact, Heracles matches Helen who was also an example of deceptive knowledge and adultery. Later, when Clement demonstrates his criticism based on Euhemerism, he states that Heracles is once again an example of deception and deceit (6.22). Thus, not only those 'sages' have buried their example of intellectual virtue and philosophy under sterile, pederastic and mythological relationships, but Clement too declares him dead by using Euhemerism: Heracles has fallen as a philosophical model, and, according to Clement, he takes down the vain Greek polytheistic world with him. The whole concept of allegorical hermeneutics has been undermined now and is ready to collapse due to the moral and epistemological destruction of the Greeks. Those who belong to the world of Appion corrupt Heracles, use a wrong moral-epistemological hermeneutics and, in fact, perfectly suit the previous mythological examples of wrong morality and wrong epistemology. After all, it is Appion himself, in line with Zeus and Heracles, who has had

59 '[...] these things can be clearly, profitably, and without prejudice to piety, set forth in an open and straightforward manner'; Riddle, Smith, 2004, 463. 
multiple women (5.3). When he fell in love, as he admitted earlier in the story, he used magic in order to 'conquer' the woman and force her to love him. When he managed to do this, he dumped her to conquer a new love. He was also the one who, as a Sophist, wrote an encomium on adultery! In this way, wrong morality and wrong epistemology typify the opponent. Heracles as the fallen philosopher is important of course in this Christian novel that clearly rejects non-Christian philosophical schools, and philosophy as such as a method of reaching knowledge. The pretensions of Clement's opponents of having the ideal knowledge, reached by offering varying hypotheses and syllogisms, are rejected in this work, even as the wrong morality, offered as different women. Clement's sickness as a young boy was a Platonic one: out of love for true knowledge, and also for the right morality.

In his refutation, Clement denounces the incoherence of the allegories and the irreverence of the myths (6.17-18). As he also said on the first day (4.25.1-2), people who use perverse myths as a 'cover' for good deeds cannot be called wise. Whether it concerns real crimes or allegorical stories hiding a respectable content, he claims this has incited people to imitate the myths into wrong ways of life and has put those mythical gods in disgrace. This was the work of evil demons who tried to convey these myths as true in order to commit crimes without any feeling of shame popping up afterwards (see also 4.12, 4.25). Therefore, Clement denounces the people behind the disgraceful hermeneutics who represent a wrong morality. They also represent the wrong knowledge: the physical and philosophical allegory is not consistent (6.19). First, some poets consider nature as the cause of the whole creation, others say it is the intellect. By combining both points of view, they have even misled the sages. Also, as to chance, how did everything get its order and proportion if the cosmos arose by chance? Order must have come into existence through superior reflection and only the intellect capable of imagining an order can also realise order. This is also a topic of debate in the rest of the Homilies, for example Hom. 3.33-34, where the role of God as Creator is questioned. ${ }^{60}$ 'Physical' allegories and philosophical hypotheses do not explain the truth. A second inconsistency (6.20) is that those who explain the deeds of the gods as physical doctrines, actually deny the existence of the gods. ${ }^{61}$ They reduce them to all kinds of physical elements. At this point in his dissertation, Clement

${ }^{60}$ Also in the Recognitions, e.g. I.20; II.21.

${ }^{61}$ We already read this argument in pre-Christian, philosophical treatises such as Cicero's De Natura Deorum. Cotta, representative of the skeptical Academia, rejects the Stoic school, represented by Balbus, because Stoic philosophers tried to rationalise (by using etymologies) gods as natural phenomena. Gods become nothing more than natural elements $(\S 3.63$, see also $\S 1.36$ where Velleius, representative of the Epicureans, rejects the allegorical hermeneutics of the Stoics). 
is once again turning to Euhemerism. The gods who are sung by the poets are

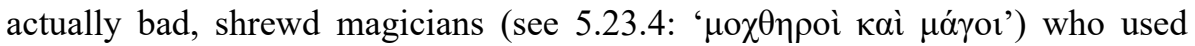
magic to undergo metamorphoses in order to destroy marriages by committing adultery. Again, Clement is attacking the morality and epistemology of the opponent's world in which magic is linked to adultery, variability and destruction. Here, Clement's criticism of Appion's allegorical hermeneutics takes an end. Clement concludes (part v).

\section{Clement's 'apophatic theology' as conclusion of the disputes (Part v)}

Clement's conclusio is remarkable (6.24). Carl Schmidt already stated in 1929, that the disputes with Appion have an abrupt ending:

Mit diesen Worten des Clemens bricht die Disputation mit Appion ganz überraschend und völlig unvermittelt ab. ${ }^{62}$

James Carleton Paget, William Adler and Patricia Duncan confirmed the same many years later. ${ }^{63}$ In their view, the arrival of Peter (6.26) interrupts the disputes between Clement and Appion in an (unexpectedly) abrupt way. However, this has to be nuanced. Clement does not know who God is, but he does know what God is, or rather, what God is not, which he explains in what we can consider an 'apophatic theological' point of view. God is not the four elements because they have a cause. He is not a mixture, combination, generation, nor the visible envelope that contains everything, nor even sediment, the water that covers the sediment, nor the boiling mass, nor the air that descends to the earth. This apophatic theological language is not unusual in the Clementines as we have already seen, but here it plays also a rhetorical role. This apophatic theology rhetorically and narratively matches with Appion's 'negated mythology'. Appion's allegorical, physical-philosophical and etymological vision is invalidated here. The very fact that Clement explains that God is not the four elements, nor generation, etc. serves as a response to the physical interpretation of Appion. Everything owes its existence to God who is the great craftsman, and not to chance, ether or the like. He is the one who produces a unique work as an intellectual creator and is not subject

${ }^{62}$ Schmidt 1929, 196.

${ }^{63}$ Adler states: 'The conclusion to the debate is unexpectedly abrupt. In the midst of Clement's discourse to Apion about providence and the existence of an artificer who designed the universe, word comes that Peter had arrived in Tyre from Caesarea and that people were flocking to meet him.'; Adler 1993, 29n38; Carleton Paget 2010, 432-433; Duncan 2017, 97. 
to any desire, power, or, in fact, Eros. God is not influenced by time and nature nor is he destructible (6.25), according to Clement. The beginning of the third day started with the list of denied myths and parallel to them, Clement ends that same day with a list of denied features of God, some sort of 'apophatic theology' at the end of the day against a 'negated mythology' at the beginning of the same day.

\section{The disputes as part of Clement's epistemological and moral journey}

A paradoxical battle? Greek paideia versus Greek paideia (Hom. 1-3 and 4-6)

The apophatic theology disapproves of the negated mythology and the accompanying allegorical, physical-philosophical explanation. In fact, this fits in with the basic idea of Hom. 4-6 and, actually, the whole work: Jewish-Christianity overpowers the pagan-philosophical attempts of claiming any form of truth, in this case mythological, allegorical and natural-philosophical methodologies. Since the beginning of the novel, we learned that Clement cannot find the truth in philosophical schools because they only provide changing hypotheses. Thereafter, he wanted to go to Caesarea, to learn more about that Christian message about which he had heard rumours. Due to a storm, a novelists' trademark, he ended up in Alexandria, where he met Barnabas. There, he refuted the idle 'philological' phi-

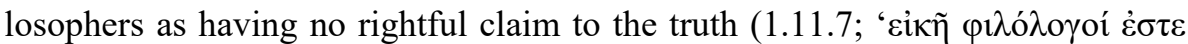

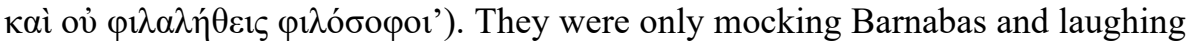
at his testimonies about Christ and his teachings (1.9). Clement has already presented himself thus as the opponent of these so-called philosophers. The same happens in Hom. 4-6 where Clement refutes Appion, who is characterised in line with these 'non-truthloving', philological philosophers. As I have discussed earlier, Appion is a man of Greek paideia, a philologist who is able to write an encomium, and a philosopher who knows allegorical explanations. There are not only many links with the 'philosophers' or 'men of Greek paideia', whom Clement met earlier in his life, but also with Simon Magus, Appion's friend and main opponent in the story. Appion, in this way, is, in general, a composite opponent (also when we compare him with the historical Apion), since he is also a magician who misleads women, a deceiving lover, and someone who is familiar with mystery cults: he embodies many wrong moral and epistemological methods. But why Clement and Appion? Clement and Appion share an important background: Greek paideia. Hom. 4-6 is a beautiful contest in Greek paideia (filled with encomium, allegories, rhetorical principles such as anaskeue, kataskeue, ethopoeia) and 
forms a fitting sequence of Hom. 1-3 where we already saw Clement being disappointed in this kind of epistemology/culture. Also in Hom. 1-3 it is mentioned that Clement knew the principles of anaskeue and kataskeue very well (1.19.3) because he had learned them in philosophical schools. While Hom. 4 and 5 discuss and reject the mythological and rhetorical elements of Greek paideia as education and culture, Hom. 6 takes a step further: the philosophical methods (in the form of Orphical, and Stoic allegorical and etymological explanations) which would 'save' Greek paideia are refuted. Heracles the philosopher, the possible saviour of Greek paideia, was the ultimate failure. This 'Greek' world has fallen, just as its defenders have: the anonymous 'philosophers', Appion, Simon, and Helen who is the ultimate link between the 'Greek' world as discourse and its representatives who are linked to this discourse and who want to defend it.

Whereas Frédéric Amsler made the remark that it is strange that Clement has several sophisticated disputes with Appion while the former has not yet been baptised and has not yet finished his initiation, ${ }^{64} \mathrm{Hom}$. 4-6 can thus be understood as a fitting sequence on narrative grounds when we look at Clement's history in Hom. 1-3. It is correct that Clement has not yet been baptised and fully initiated, which could explain his apophatic language. Clement is still on his way to find truth and salvation, in the footsteps of Peter, which results in his baptism in Hom. 11.35. Only when he is baptised, inducted into the pure, pious and chaste life choice and into the true and truthful Christian background, he is ready to find his family with the help of Peter, apostle of the True Prophet, and ready to understand God, which will be explained by that same Peter, in the discussions with Simon at the end of the Homilies (16-20). He was, however, ready to reject Greek paideia, the 'philosophical' schools and their hypotheses, which were the subjects of Hom. 4-6 and also 1-3. Moreover, he did this in a superseding way: he is a clear exponent of Greek paideia itself. The disputes with Appion deal with this 'Greek' world, not with Scriptural problems or the like. Clement, as an initiate-in-spe, can only deal superficially with the question who or what God is but he is able to reject philosophical hypotheses and methods concerning these questions. Peter's arrival is not abrupt, he is the right person to elaborate what Clement has already touched upon.

Consequences of being part of the 'Greek' world (Hom. 4-6 and Peter's arrival)

People suffer from diseases due to their wrong moral and epistemological habits. Demons gain control over people when the latter believe what is untrue about

${ }^{64}$ Amsler 2005, 346-347. 
God, offer and eat sacrificial meat, or, in other words, are guilty of a wrong morality and epistemology. An interesting image here is 'rabies'. It connects the disputes between Appion and Clement with the rest of the work, especially Peter in Hom. 7.4.2-5 (after he has arrived in Tyre) and 8.12 (in Tripolis). Just as Peter in the later cases, Clement describes the effects of the Greek paideia in a register of ritual purity ${ }^{65}$ and defilement, again showing the link between Hom. 4-6 and the rest of the Homilies. This defilement is contagious as can be noticed in cities where people commit more sins than people in rural areas, where one is excluded from the paideia in the cities (4.18.1). Greek culture is not a rural phenomenon, but an urban one, ${ }^{66}$ and should be avoided (such as myths, theatres, literature; 4.19.3). This culture propagates adultery through its myths, theatre etc. which is also described in terms of contagious defilement. Clement compares committing adultery and the accompanying bad consequences to a man being killed by a rabid dog (4.21). Hence, students, still having flexible minds, should avoid this Greek paideia and in particular, the adulterous myths (5.25-26). The same consequences are applied to idolatry and polytheism in the following Homilies. They defile the soul and the body $(7.3 .1-4 ; 8.4 ; 8.15 .1-20.4 ; 9.9 .1-4)$. According to Peter, Giants shedded polluted blood into the air and brought sickness in the world. After the purifying Flood, these Giants became the evil demons. People offered sacrificial meat and ate it. This caused the pollution of their souls and bodies, and let the demons have control over them. These demons were also at the root of Greek paideia as Clement stated on the first day of his disputes with Appion (4.12.1). Peter is there to the rescue: he is able to explain the workings of the demons to the crowd and to heal them (7.1 and further) after the disputes between Appion and Clement. Meanwhile, Appion had left the scene, just as Simon always does after a dispute with Peter (forced e.g. 7.22, or unforced e.g. 19.25).

\section{Conclusion}

In conclusion, I wanted to offer a new approach to Hom. 6, the third day of the disputes between Appion and Clement in line with the rhetorical and narrative research context. I suggested that the disputes have an interesting narrative function (which was neglected by the Quellenanalyse) and that they have a careful

\footnotetext{
${ }^{65}$ See also Reed 2008, 430-431, and De Vos 2019, 75-76.

${ }^{66}$ This is a quaestio according to Quintilianus' Institutio Oratoria 2.4.24: 'Theses autem quae sumuntur ex rerum comparatione (ut 'rusticane vita an urbana potior' [...])'. The representation of an 'anti-polis'-utopia is remarkable, given that Christianity was in the beginning an urban phenomenon.
} 
ring construction. This construction consists of a 'negated mythology' (I), which is Appion's criticism of the literal hermeneutics of Clement (IA), Appion's allegorical explanation (II), the turning point (III) when Clement takes the floor, his allegorical dissertation as a 'pseudo-Appion' (IV) and, thereafter, his criticism of the hermeneutics of Appion (IVA). Clement concluded with his 'apophatic theology' (v). It is very interesting to notice how the structure of Appion's 'negated mythology' is being filled in, partly by Appion himself, and partly by Clement, remarkably, as a 'pseudo-Appion' (as has been shown in the scheme). It has turned out that Clement's role as a 'pseudo-Appion' was not neutral. He was changing the focus on the way of interpreting (instead of a physical-philosophical explanation, it was a moral-epistemological one) in order to prepare his criticism of Appion's hermeneutics later on (IVA) and in fact the opponent's culture. In this way, the rhetorical richness of Appion's and Clement's expositions and the way how Clement rhetorically adapts himself against the Sophist-grammarian-philosopher Appion, is strongly linked with the particular ring construction. In the end, Appion's physical-philosophical, and etymological point of view is overruled by Clement's 'apophatic theology'. This apophatic theology has its place in Clement's quest for the truth in the rest of the work. This shows how these disputes play a role in the whole work, just as Clement's game with Helen and Heracles as symbols of the wrong morality and epistemology of his opponent's world. In these disputes between Clement and Appion, not only the myths and allegories of Appion are attacked, but also the wrong morality and epistemology of the "philosophical' opponents and of the whole world of Helen and Simon in the rest of the Homilies, and this in a clever way. ${ }^{67}$

\section{Bibliography}

Adler, W. 1993. 'Apion's "Encomium of Adultery”: A Jewish Satire of Greek Paideia in the Pseudo-Clementine Homilies', Hebrew Union College Annual 64, 15-49.

Albrile, E. 2000. 'L'Uovo del Fenice, aspetti di un sincretismo orfico-gnostico', Le Muséon $113,55-85$.

${ }^{67}$ I would like to express my sincere gratitude to my supervisor, Prof. dr. Danny Praet (Ghent University), and my co-supervisor, Prof. dr. Koen De Temmerman (Ghent University), who have read and discussed several drafts of this paper. I also wish to thank the anonymous Ancient Narrative referees for the useful comments and suggestions. I thank Daniël De Coen for improving the English grammar of this article, remaining mistakes are mine. And last but not least, I wish to thank Em. Prof. Dr. Bernard Pouderon for sending to me several contributions of his in order to initiate me even more in the world of Pseudo-Clement. 
Amsler, F. 2005. 'Les Homélies du Pseudo-Clément ou comment justifier l'octroi d'une chaire d'enseignement à un croyant d'origine païenne', in C. Focant et A. Wénin (eds.), Analyse narrative et bible. Deuxième colloque international du RRENAB, Louvain-La-Neuve, Avril 2004, Leuven: Peeters, 337-350.

Amsler, F. 2014². 'Peter and his secretary in Pseudo-Clement', in P.R. Davies and T. Römer (eds.), Writing the Bible. Scribes, Scribalism and Script, London and New York: Routledge-Taylor \& Francis Group, 177-188.

Bekker, I. (ed.), Apollonius Sophista. 1833. Lexicon Homericus, Berlin: Reimer.

Benaissa, A. 2014. '5202. Copy of an Inscription for Apion', in W.B. Henry e.a. (eds.), The Oxyrhynchus Papyri, Volume LXXIX, Oxford: The Egypt Exploration Society, 125-138.

Bernabé, A. 2004. Poetae Epici Graeci Testimonia et Fragmenta, Pars II: Orphicorum et Orphicis similium Testimonia et Fragmenta, München/Leipzig: In Aedibus K.G. Saur.

Bonnet, C. 1988. Melqart: Cultes et mythes de l'Héraclès tyrien en Méditerranée, Leuven: Peeters.

Bowie, E. 2004. 'The geography of the Second Sophistic : Cultural variations', in B.E. Borg, Paideia: The World of the Second Sophistic, Berlin : Walter de Gruyter, 65-84.

Bremmer, J.N. 2010. 'Apion and Anoubion in the Homilies', in J.N. Bremmer (ed.), The Pseudo-Clementines. Studies on Early Christian Apocrypha 10, Leuven: Peeters, 72-91.

Bremmer, J.N. 2017. Maidens, Magic, and Martyrs in Early Christianity, Tübingen: Mohr Siebeck.

Brisson, L. 1990. 'Orphée et l'Orphisme à l'époque impériale.', in W. Haase and H. Temporini (eds.), Aufstieg und Niedergang der Römischen Welt (II.36.4), Berlin/New York: de Gruyter, 2867-2932.

Burkert, W. 1987. Ancient Mystery Cults, Cambridge: Harvard University Press.

Carleton Paget, J. 2010. Jews, Christians and Jewish Christians in Antiquity (Wissenschaftliche Untersuchungen zum Neuen Testament [251]), Tübingen: Mohr Siebeck.

Carlson, D.H. 2013. Jewish-Christian Interpretation of the Pentateuch in the Pseudo-Clementine Homilies, Minneapolis: Fortress Press.

Côté, D. 2001. Le thème de l'opposition entre Pierre et Simon dans les Pseudo-Clémentines. Paris: Institut d'Études Augustiniennes.

Côté, D. 2015. 'Rhetoric and Jewish-Christianity: the Case of the Grammarian Apion in the Pseudo-Clementine Homilies', in P. Piovanelli and T. Burke (eds.), Rediscovering the Apocryphal Continent: New Perspectives on Early Christian and Late Antique Apocryphal Texts and Traditions, Tübingen: Mohr Siebeck, 369-390.

Cumont, F., Van Haeperen, F., Bonnet, C. (eds.) 20094. Les Religions Orientales Dans Le Paganisme Romain, Torino: Nino Aragno.

De Vos, B. 2017. 'Retoriek en dialectiek in de Pseudo-Clementinen: de zoektocht naar de ware Sophia in de disputen met Appion', Tetradio 25, 203-29.

De Vos, B. 2019. 'The Role of the Homilistic Disputes with Appion (Hom. 4-6)', Vigiliae Christianae 73.1, 54-88.

Dillery, J. 2003. 'Putting Him Back Together Again: Apion Historian, Apion Grammatikos', Classical Philology 98.4, 383-390.

Duncan, P. 2017. Novel Hermeneutics in the Greek Pseudo-Clementine Romance (Wissenschaftliche Untersuchungen zum Neuen Testament [395]), Tübingen: Mohr Siebeck.

Edwards, M. 1992. 'The Clementina: A Christian Reponse to the Pagan Novel', Classical Quarterly 42, 459-474.

Galpérine, M.-C. (ed.), Damascius. 1987. Des premiers principes. Apories et résolutions, Lagrasse: Verdier. 
Geoltrain, P. and Kaestli, J.-D (eds.). 2005. Écrits apocryphes chrétiens tome II, Paris: Gallimard.

Gruppe, O. 1887. Die Griechische Culte und Mythen in ihren Beziehungen zu den orientalischen Religionen. Erster Band, Leipzig: B.G. Teubner.

Haar, S. 2003. Simon Magus: The First Gnostic?, Berlin/New York: de Gruyter.

Harris, R. 1921. 'Notes on the Clementine Romances', Journal of Biblical Literature 40.3/4, 125-145.

Haslam, M.W. 1994. 'The Homer "Lexicon of Apollonius Sophista" I. Composition and Constituents', Classical Philology 89.1, 1-45.

Heintze, W. 1914. Der Clemensroman und seine griechischen Quellen, Leipzig: J.C. Hinrichs.

Jones, F.S. 1982. 'The Pseudo-Clementines: A History of Research, Part I and Part II', The Second Century 2, 1-33, 63-96.

Jones, F.S. 2012. 'Introduction to the Pseudo-Clementines', in F.S. Jones, Pseudoclementina Elchasaiticaque inter Judaeochristiana. Collected Studies. Leuven: Peeters, 7-49.

Jones, F.S. 2012. 'Clement of Rome and the Pseudo-Clementines: History and/or Fiction', in F.S. Jones, Pseudoclementina Elchasaiticaque inter Judaeochristiana. Collected Studies. Leuven: Peeters, 172-193.

Jones, F.S. 2014. The Syriac Pseudo-Clementines. An Early Version of the First Christian Novel. Translated into English by F. Stanley Jones, Turnhout: Brepols.

Jones, F.S. 2019. 'The Orphic Cosmo-Theogony in the Pseudo-Clementines', in G. Bady and D. Cuny (eds.), Les polémiques réligieuses du Ier au IVe siècle de notre ère. Hommage à Bernard Pouderon, Paris: Beauchesne, 71-82.

Jourdan, F. 2010-2011. Orphée et les chrétiens. La reception du mythe d'Orphée dans la literature chrétienne grecque des cinq premiers siècles, Paris: Les Belles Lettres.

Kelley, N. 2006. Knowledge and religious authority in the Pseudo-Clementines: situating the Recognitions in fourth-century Syria. Tübingen: Mohr Siebeck.

Kern, O. 1922. Orphicorum Fragmenta, Berlin: Weidmann.

Lucian. 1913. Phalaris. Hippias or The Bath. Dionysus. Heracles. Amber or The Swans. The Fly. Nigrinus. Demonax. The Hall. My Native Land. Octogenarians. A True Story. Slander. The Consonants at Law. The Carousal (Symposium) or The Lapiths. Translated by A. M. Harmon. Loeb Classical Library 14. Cambridge, MA: Harvard University Press.

MacDowell, D.M. (ed.), Gorgias. 2005. Encomium of Helen. London: Bristol Classical Press.

MacRae, D. 2019. 'Simon the God: Imagining the Other in Second-Century Christianity', in J. Tolan (ed.), Geneses: A Comparative Study of the Historiographies of the Rise of Christianity, Rabbinic Judaism, and Islam, Abingdon: Routledge, 64-86.

Nesterova, O. 2008. 'L'attitude à l'égard de l'allégorie païenne chez les auteurs du corpus pseudo-Clémentin', in F. Amsler, e.a. (ed.), Nouvelles intrigues pseudo-clémentines. Plots in the Pseudo-Clementine Romance. Actes du deuxième colloque international sur la littérature apocryphe chrétienne, Lausanne-Genève, 30 août - 2 septembre 2006, Belfort: Prahins, 397- 408.

Pépin, J. 1958. Mythe et Allégorie: les origines grecques et les contestations judéo-chrétiennes, Paris: Aubier.

Pernot, L. 1993. La rhétorique de l'éloge dans le monde gréco-romain, Paris: Institut d'Études Augustiniennes.

Pouderon, B. 2012. 'Dédoublement et creation romanesque dans le roman pseudo-Clémens', in B. Pouderon (ed.), La Genèse du Roman Pseudo-Clémentin. Études littéraires et historiques, Paris-Louvain-Walpole, MA: Peeters, 3-19. 
Pouderon, B. 2012a. 'Aux origines du Roman pseudo-clémentin. Prototype païen, refonte judéo-hellénistique, remaniement chrétien', in B. Pouderon (ed.), La Genèse du Roman Pseudo-Clémentin. Études littéraires et historiques, Paris-Louvain-Walpole, MA: Peeters, 21-46.

Pouderon, B. 2012b. 'Clément, évèque de Rome, double littéraire du consul Flavius Clemens', in B. Pouderon (ed.), La Genèse du Roman Pseudo-Clémentin. Études littéraires et historiques, Paris-Louvain-Walpole, MA: Peeters, 49-71.

Pouderon, B. 2012c. 'Matthidia la prosélyte', in B. Pouderon (ed.), La Genèse du Roman Pseudo-Clémentin. Études littéraires et historiques, Paris-Louvain-Walpole, MA: Peeters, 73-84.

Reed, A.Y. 2008. 'From Judaism and Hellenism to Christianity and Paganism: Cultural Identities and Religious Polemics in the Pseudo-Clementine Homilies', in F. Amsler, e.a. (ed.), Nouvelles intrigues pseudo-clémentines. Plots in the Pseudo-Clementine Romance. Actes du deuxième colloque international sur la littérature apocryphe chrétienne, Lausanne-Genève, 30 août - 2 septembre 2006, Belfort: Prahins, 251-259.

Rehm, B. 1953. Die griechischen christlichen Schriftsteller der ersten Jahrhunderte. Die Pseudoklementinen I Homilien, Berlin: Akademie.

Rehm, B. 1956. Die griechischen christlichen Schriftsteller der ersten drei Jahrhunderte. Die Pseudoklementinen II. Rekognitionen in Rufins Übersetzung.

Richardson, E.C. 1895. 'The History of Clement', The Prebyterian and reformed review 6, 108113.

Riddle, M.B., Smith. T. e.a. 20044. 'Pseudo-Clementine Literature', in A. Roberts and J. Donaldson (eds.), The Writings of the Fathers Down to A.D. 325. Ante-Nicene Fathers Volume 8. The Twelve Patriarchs, Excerpts and Epistles, The Clementina, Apocrypha, Decretals, Memoirs of Edessa and Syriac Documents, Remains of the First Ages, Peabody (Ma): Hendrickson, 364-620.

Roig Lanzillotta, L. 2010. 'Orphic Cosmogonies in the Pseudo-Clementines? Textual Relationship, Character and Sources of Homilies 6.3-13 and Recognitions 10.17-19.30.', in J.N. Bremmer (ed.), The Pseudo-Clementines. Studies on Early Christian Apocrypha 10, Leuven: Peeters, 115-141.

Schiebe, M.W. 2012. 'Chrysippos und das obszöne Bild von Zeus und Hera. Eine forschungskritische Stichtung der Evidenz', Mnemosyne 65.3, 469-79.

Schmidt, C. 1929. Studien zu den Pseudo-Clementinen, Leipzig: J.C. Hinrichs.

Siouville, A. 1991. Les Homélies Clémentines, Lagrasse: Verdier.

Strecker, G. 1958. Das Judenchristentum in den Pseudoklementinen, Berlin: Akademie.

Trzaskoma, S.M., Smith, R.S., and Brunet, S. (eds.). 2004. Anthology of Classical Myth: primary sources in translation, Indianapolis: Hackett Publishing Company.

Vähäkangas, P. 2012. Rejection and Reception of Philosophy in the Letter of Eugnostos (NHC III, 3 and V,1) and Pseudo-Clementine Recognitions, (unpublished thesis, defended the Faculty of Theology, University of Helsinki).

Van Amersfoort, J. 1981. 'Traces of an Alexandrian Orphic Theogony in the Pseudo-Clementines', in R. Van Den Broek and M.J. Vermaseren (eds.), Studies in Gnosticism and Hellenistic Religions, presented to Gilles Quispel on the Occasion of his 65th Birthday, Leiden: Brill, 13-30.

Van der Horst, P.W. 2002. 'Who was Apion?', in P.W. Van der Horst, Japheth in the Tents of Shem, Studies on Jewish Hellenism in Antiquity, Leuven: Peeters, 207-222.

Waitz, H. 1904. 'Simon Magus in der altchristlichen Literatur', Zeitschrift für die Neutestamentliche Wissenschaft, 121-143. 
Waite, H. 1904. Die Pseudoklementinen, Homilien und Rekognitionen. Eine Quellenkritische Untersuchung, Leipzig: J.C. Hinrichs.

Webb, R. 2001. The Progymnasmata as Practice, in: Y.L. Too, Education in Greek and Roman Antiquity, Leiden: Brill, 289-316.

Whitmarsh, T. 2005. The Second Sophistic, Cambridge: Cambridge University Press. 